\title{
Posterior mediastinal ganglioneuroma presenting with wheezing in a young Sri Lankan girl
}

\author{
*Vishnu Sivapatham ${ }^{1}$, Sumudu N Seneviratne ${ }^{2}$ \\ Sri Lanka Journal of Child Health, 2020; 49(3): 303-305 \\ http://dx.doi.org/10.4038/sljch.v49i3.9156 \\ (Key words: Childhood ganglioneuroma, posterior mediastinal mass, wheezing)
}

\section{Introduction}

Neuroblastomas, ganglioneuromas, and ganglioneuroblastomas are a group of neuroblastic tumours originating from neural crest cells of the sympathetic nervous system ${ }^{1}$. Ganglioneuroma (GN) is an uncommon tumour consisting wholly of mature Schwann cells, ganglion cells and nerve fibres. They are devoid of neuroblasts, intermediate cells and mitotic figures ${ }^{2,3}$. Common sites where GNs are found include the mediastinum, retroperitoneum and adrenal glands ${ }^{4}$. Though GN is a benign tumour, local invasive growth can produce symptoms due to mass effects on surrounding organs. Rarely GNs secrete vasoactive intestinal polypeptides, catecholamines and androgens leading to flushing or secretory diarrhoea ${ }^{3}$.

\section{Case report}

A 7-year-old girl presented with cough and dyspnoea of one day's duration. She had intermittent episodes of cough and wheezing for the last three years, which were treated with short acting bronchodilators. There was no diurnal variation of cough or any family history of asthma. She was not on long term prophylaxis with inhaled steroids. Examination revealed an adequately grown child with mild respiratory distress. Her respiratory rate was 32 breaths per minute. She had bilateral rhonchi, and $\mathrm{SpO}_{2}$ was $96 \%$ on air. She had no nasal flaring, subcostal or intercostal recessions or clubbing, and no other abnormalities were detected on systemic examination. On further evaluation, chest radiograph demonstrated a

${ }^{1}$ Lecturer in Paediatrics, Department of Clinical Sciences, Eastern University, Sri Lanka, ${ }^{2}$ Consultant Paediatric Endocrinologist and Senior Lecturer, Department of Paediatrics, Faculty of Medicine, University of Colombo, Sri Lanka, *Correspondence: vishnukumars@esn.ac.lk

(iD)

orcid.org/ 0000000333206016

(Received on 25 January 2019: Accepted after revision on 22 March 2019)

The authors declare that there are no conflicts of interest

Personal funding was used for the project.

Open Access Article published under the Creative

Commons Attribution CC-BY (CC) (P) homogeneous round lesion occupying the right upper thorax with tracheal deviation to the left side (Figure 1).

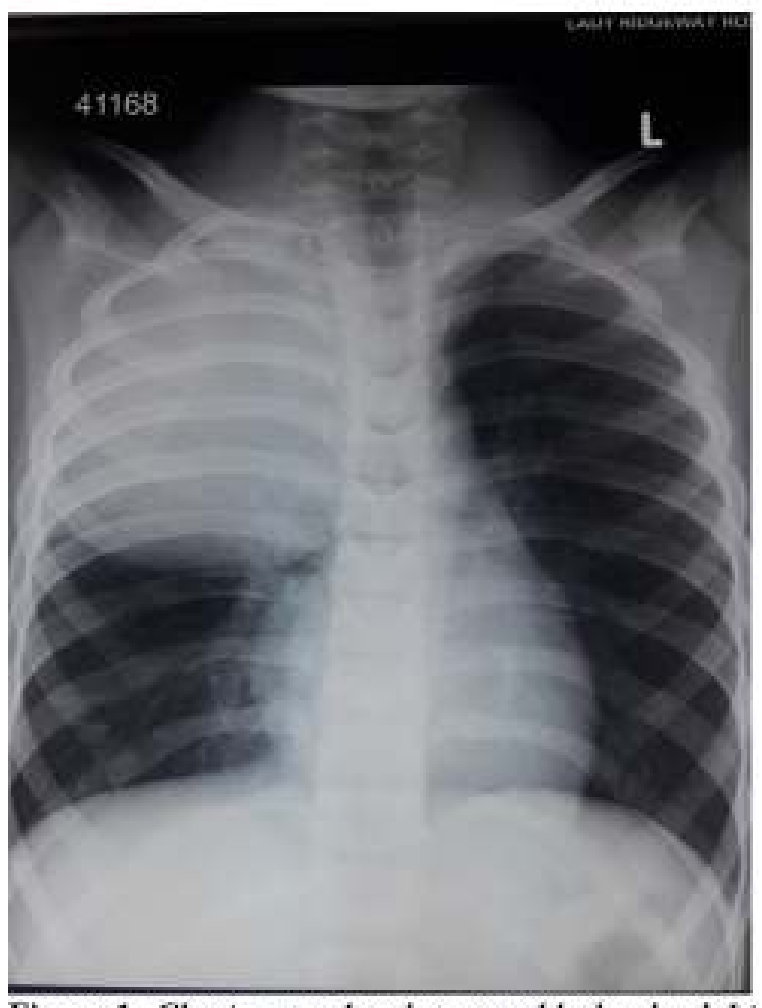

Figure 1: Chest $x$-ray showing round lesion in right upper thorax

Magnetic resonance imaging (MRI) of the chest revealed a large posterior mediastinal mass extending to the right upper hemithorax in favour of a ganglioneuroma with no intra-spinal extension and a small adjacent reactive pleural effusion (Figure 2).

Complete blood count, blood film, serum electrolytes, urea, creatinine and liver function tests were normal. 24-hour urinary vanillyl mandelic acid (VMA) excretion was $4.3 \mathrm{mg} / 24$ hours (reference range $11-11 \mathrm{mg}$ ). She underwent thoracotomy and surgical excision of the tumour (Figure 3). 


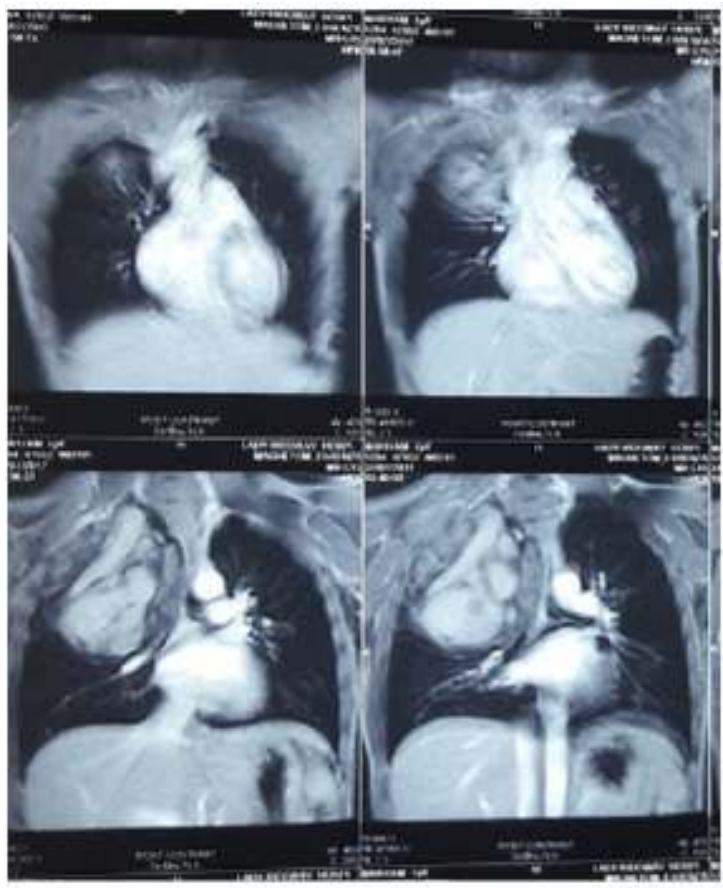

Figure 2: MRI of chest showing posterior mediastinal mass

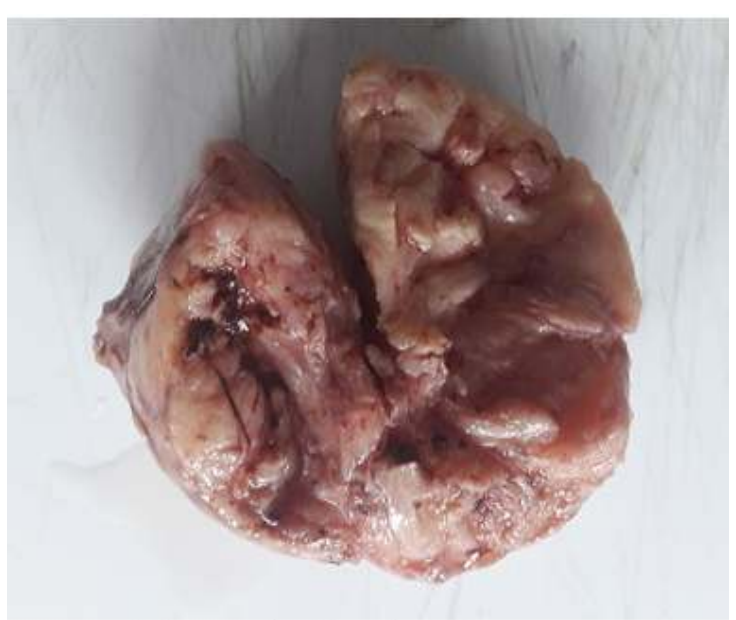

Figure 3: Excised tumour

Histological examination of the resected tumour showed a neurofibrillary background with scattered ganglion cells intermingled with mature adipocytes without any neuroblasts. She developed Horner's syndrome on the right side in the postoperative period.

\section{Discussion}

GNs affect children and young people usually below 20 years of age (median age of diagnosis 7 years), females being slightly more predominant ${ }^{4,5}$. Frequent locations include posterior mediastinum (41.5\% of cases), retroperitoneum (37.5\%), adrenal gland $(21 \%)$, and neck $(8 \%)$ and clinical features mainly depend on location ${ }^{2,6}$. GN mainly presents as an asymptomatic mass found on routine radiography of the chest. Our patient presented with cough and wheezing due to the mass effect and the diagnosis was suspected on chest $\mathrm{x}$-ray findings. Similar chest radiographs are found in teratoma, ganglioneuroblastoma and round pneumonia.

GNs are considered by some to be the benign counterpart of neuroblastomas. Both tumours arise from neural crest cells of the sympathetic nervous system $^{3,5}$. Most investigators believe that ganglioneuromas result from the maturation of neuroblastoma cells to ganglion cells ${ }^{7}$. The prognosis of GN is very good and recurrences are uncommon following surgery ${ }^{8}$. Rarely, GN secretes enough VMA or homovanillic acid to present with flushing and secretory diarrhoea ${ }^{2}$. Our patient had only the mass effect of the tumour and no features of catecholamine excess. The recommended treatment is complete surgical resection to relieve mass effect of the tumour.

\section{Acknowledgements}

We thank Dr. R A N K Samarasinghe, Consultant Radiologist, Lady Ridgeway Hospital for Children, for her invaluable help..

\section{References}

1. Serin HI, Gorkem SB, Doganay S, Ciracı $\mathrm{S}$, Unal E, Guzel $\mathrm{M}$, et al. Diffusion weighted imaging in differentiating malignant and benign neuroblastic tumors. Japanese Journal of Radiology 2016; 34(9): 620-4.

https://doi.org/10.1007/s11604-016-0565-

PMid: 27418194

2. Lonergan GJ, Schwab CM, Suarez ES, Carlson CL. Neuroblastoma, ganglioneuroblastoma and ganglioneuroma: Radiologic-pathologic correlation. Radiographics 2002; 22(4):911-34.

https://doi.org/10.1148/radiographics.22.4. g02j115911

PMid: 12110723

3. Alqoaer KI, Albalawi M, Alnoaiji MS, Khan A. Case Report: Mediastinal ganglioneuroma Presented as chronic diarrhoea in a young Saudi Girl. International Journal of Clinical Medicine 2014; 5:420-4.

https://doi.org/10.4236/ijcm.2014.57057

4. Rathod SG, Tangde AR, Sonwane BR, Bindu RS. Adrenal ganglioneuroma: rare cause of gross haematuria. International Journal of Current Medical and Pharmaceutical Research 2016; 2(8):5112. 
5. Hayes FA, Green AA, Rao BN. Clinical manifestations of ganglioneuroma. Cancer 1989; 63(6):1211-4.

https://doi.org/10.1002/10970142(198903

15)63:6<1211::AIDCNCR2820630628>3. $0 . \mathrm{CO} ; 2-1$

6. Jain M, Shubha BS, Sethi S, Banga V, Bagga D. Retroperitoneal ganglioneuroma: Report of a case diagnosed by fine-needle aspiration cytology, with review of the literature. Diagnostic Cytopathology 1999; 21(3):194-6.

https://doi.org/10.1002/(SICI)10970339(1 99909)21:3<194::AID-DC9>3.0.CO;2-B

7. Goldman RL, Winterling AN, Winterling CC. Maturation of tumors of the sympathetic nervous system. Report of long-term survival in 2 patients, one with disseminated osseous metastases, and review of cases from the literature. Cancer 1965; 18(11):1510-6.

https://doi.org/10.1002/10970142(196511) 18:11<1510::AIDCNCR2820181124>3.0. $\mathrm{CO} ; 2-\mathrm{H}$

8. Rha SE, Byun JY, Jung SE, Chun HJ, Lee $\mathrm{HG}$, Lee JM. Neurogenic tumours in the abdomen: Tumour types and imaging characteristics. Radiographics 2003; 23(1): 29-43

https://doi.org/10.1148/rg.231025050 